\title{
FAKTOR-FAKTOR YANG BERPENGARUH TERHADAP PENERIMAAN OPINI GOING CONCERN PADA PERUSAHAAN MANUFAKTUR YANG MENGALAMI FINANCIAL DISTRESS
}

\author{
Ida Ayu Budhananda Munidewi ${ }^{*}$, Nyoman Angga Pradipa ${ }^{2 *}$ \\ ${ }_{1}^{1}$ Prodi Akuntansi, Fakultas Ekonomi, Universitas Mahasaraswati Denpasar \\ ${ }^{2}$ Prodi Akuntansi, Fakultas Ekonomi, Universitas Mahasaraswati Denpasar \\ *Email korespondensi: budhananda@unmas.ac.id
}

\begin{abstract}
Going concern audit opinion is an audit opinion issued by the auditor to ascertain whether the company can maintain its survival or not. The survival of a business entity is influenced by internal constraints, namely constraints within the company itself such as financial conditions, human resources, corporate culture, mastery of technology, internal supervision, etc. and external conditions can be constraints outside the company such as markets, monetary conditions, social, politics and others. Several studies show that the factors that encourage auditors to issue going concern opinions are different and the results are not conclusive. So, this study aims to reexamine the factors that influence the going concern audit opinion. The factors tested in this study are liquidity, audit firm reputation, previous year's audit opinion, and company size. This study uses manufacturing companies that experienced financial distress on the Indonesia Stock Exchange in 2014-2016 as a research sample. The results of purposive sampling, obtained a number of 31 manufacturing companies that meet the sample criteria. Testing the hypothesis in this study using logistic regression analysis. The test results show that only the previous year's audit opinion affected the acceptance of the going-concern audit opinion. Meanwhile, the variable liquidity, KAP reputation, and company size do not affect the acceptance of going-concern audit opinion.
\end{abstract}

Keywords: going concern audit opinion, liquidity, audit firm reputation, previous year's audit opinion, company size

\begin{abstract}
Abstrak
Opini audit going concern merupakan opini audit yang dikeluarkan oleh auditor untuk memastikan apakah perusahaan dapat mempertahankan kelangsungan hidupnya atau tidak. Keberlangsungan hidup entitas bisnis dipengaruhi oleh kendala internal yaitu kendala di dalam perusahaan itu sendiri seperti kondisi keuangan, sumber daya manusia, budaya perusahaan, penguasaan teknologi, pengawasan internal, dan lain-lain dan kondisi eksternal dapat berupa kendala di luar perusahaan seperti pasar, kondisi moneter, sosial, politik dan lain-lain. Beberapa penelitian menunjukkan bahwa faktor yang mendorong auditor dalam menerbitkan opini going concern berbeda-beda dan hasilnya tidak konklusif. Jadi, penelitian ini bertujuan untuk menguji kembali faktor-faktor yang mempengaruhi opini audit going concern. Faktor-faktor yang diuji dalam penelitian ini adalah likuiditas, reputasi KAP, opini audit tahun sebelumnya, dan ukuran perusahaan. Penelitian ini menggunakan perusahaan manufaktur yang mengalami financial distress di Bursa Efek Indonesia tahun 2014-2016 sebagai sampel penelitian. Adapun hasil dari purposive sampling, diperoleh sejumlah 31 perusahaan manufaktur yang memenuhi kriteria sampel. Pengujian hipotesis dalam penelitian ini menggunakan analisis regresi logistik. Hasil pengujian menunjukkan bahwa hanya opini audit tahun sebelumnya yang berpengaruh terhadap penerimaan opini audit going concern. Sedangkan, variabel likuiditas, reputasi KAP, dan ukuran perusahaan tidak berpengaruh terhadap penerimaan opini audit going concern.
\end{abstract}

Kata Kunci: opini audit going concern, likuiditas, reputasi KAP, opini audit tahun sebelumnya, ukuran perusahaan 


\section{PENDAHULUAN}

\section{Latar Belakang}

Salah satu cara untuk menilai kondisi perekonomian dalam suatu negara yaitu dengan melihat pergerakan dunia bisnis negara tersebut. Apabila pergerakan dunia bisnis naik, maka pertumbuhan ekonomi dalam negara tersebut sedang dalam keadaan baik. Sebaliknya, bila pergerakan dunia bisnis turun yang biasanya ditandai dengan melemahnya pertumbuhan ekonomi maka menandakan ekonomi negara tersebut dalam keadaan buruk. Oleh karena itu, dunia bisnis dapat dijadikan indikator dalam menilai apakah kondisi perekonomian negara tersebut sedang dalam keadaan baik atau buruk.

Kebangkrutan perusahaan-perusahaan besar di Amerika seperti Enron merupakan salah satu contoh terjadinya kegagalan bisnis. Hal ini terjadi karena adanya skandal akuntansi yang melibatkan pihak manajemen dan auditor eksternal. Kondisi tersebut mengakibatkan anjloknya nilai tukar rupiah dan turunnya indeks harga saham karena larinya investor asing dan pelarian modal baik dari pasar saham maupun obligasi pemerintah di Indonesia. Selain itu, kebangkrutan yang dialami oleh perusahaan besar di Amerika berdampak pada entitas bisnis di Indonesia yang menyebabkan banyak perusahaan mengalami kebangkrutan karena tidak mampu mempertahankan kelangsungan hidupnya.

Contoh kasus tersebut sangat memukul profesi akuntan terutama akuntan publik karena auditor merupakan pihak yang paling bertanggungjawab dalam menilai kewajaran laporan keuangan perusahaan. Selain itu, auditor juga memiliki kewajiban untuk mengungkapkan permasalahan mengenai kelangsungan hidup (going concern) perusahaan klien jika terdapat indikasi kebangkrutan yang sangat kuat pada perusahaan dalam periode waktu tertentu.

Auditor mempunyai peranan penting dalam menjembatani antara kepentingan investor sebagai pengguna laporan keuangan dan kepentingan perusahaan sebagai penyedia laporan keuangan. Data perusahaan akan lebih mudah dipercaya oleh investor dan pemakai laporan keuangan lainnya apabila laporan keuangan tersebut mencerminkan kinerja dan kondisi perusahaan dan telah mendapat pernyataan wajar oleh auditor. Pernyataan auditor diungkapkan melalui opini audit.

Auditor akan memberikan opini atas hasil penilaiannya terhadap laporan keuangan perusahaan. Auditor yang independen akan memberikan opini sesuai dengan kondisi perusahaan sebenarnya. Jika dalam proses identifikasi informasi mengenai kondisi perusahaan auditor tidak menemukan adanya kesangsian besar terhadap kemampuan entitas untuk mempertahankan kelangsungan hidupnya, maka auditor akan memberikan opini audit non going concern dan opini audit going concern akan diberikan kepada perusahaan yang oleh auditor diragukan kemampuannya dalam menjaga kelangsungan usaha perusahaan. 
Opini audit going concern merupakan opini audit yang dikeluarkan oleh auditor untuk memastikan apakah perusahaan dapat mempertahankan kelangsungan hidupnya atau tidak. Keberlangsungan hidup entitas bisnis dipengaruhi oleh kendala internal yaitu kendala di dalam perusahaan itu sendiri seperti kondisi keuangan, sumber daya manusia, budaya perusahaan, penguasaan teknologi, pengawasan internal, dan lain-lain dan kondisi eksternal dapat berupa kendala di luar perusahaan seperti pasar, kondisi moneter, sosial, politik dan lain-lain.

Faktor yang mempengaruhi auditor mengeluarkan opini audit going concern penting untuk diketahui karena opini ini dapat dijadikan referensi investor berkaitan dengan investasinya. Beberapa penelitian menunjukkan bahwa faktor yang mendorong auditor dalam menerbitkan opini going concern berbeda-beda dan hasilnya tidak konklusif. Masalah going concern pun merupakan hal yang sangat kompleks dan terus ada hingga saat ini, sehingga diperlukan faktor-faktor sebagai tolak ukur yang pasti untuk menentukan status going concern pada perusahaan.

Sejumlah penelitian telah mengungkapkan faktor-faktor yang berpengaruh terhadap penerimaan opini audit going concern. Ramadhany (2004), Rahman \& Siregar (2012), Sari (2012), Arisandy (2015), Anita (2017), Ardiani, Nur DP, \& Azlina (2012), Praptitorini \& Januarti (2011), Meriani \& Krisnadewi (2012), Arsianto \& Rahardjo (2013), Januarti \& Fitrianasari (2008), Kristiana (2012), Edza (2015), Arma (2013), Sutedja (2010), Rahayu \& Pratiwi (2011), Santosa \& Wedari (2007), Rudyawan \& Badera (2009), Kartika (2012), Alichia (2013), serta Sussanto \& Aquariza (2012), telah berhasil meneliti tentang faktor-faktor yang berpengaruh secara signifikan terhadap penerimaan opini audit going concern oleh auditor.

Salah satu faktor yang berpengaruh terhadap penerimaan opini audit going concern adalah likuiditas. Januarti \& Fitrianasari (2008) mengungkapkan bahwa likuiditas memiliki pengaruh negatif yang signifikan terhadap opini audit going concern. Hal ini disebabkan semakin tingginya likuiditas, maka perusahaan dianggap mampu untuk melakukan kewajiban jangka pendeknya sehingga dapat menghindarkan dari penerimaan opini audit going concern oleh auditor. Penelitian Pradika \& Sukirno (2017) menyatakan bahwa likuiditas berpengaruh terhadap opini going concern perusahaan.

Reputasi KAP (Kantor Akuntan Publik) dianggap memiliki pengaruh terhadap opini audit going concern. KAP dengan reputasi big four dianggap memiliki kualitas audit yang lebih baik dibandingkan dengan KAP non big four. Junaidi \& Hartono (2010) dalam penelitiannya membuktikan bahwa reputasi KAP memiliki pengaruh positif yang signifikan terhadap opini audit going concern yang diberikan auditor. Sedangkan, penelitian yang dilakukan Januarti \& Fitrianasari (2008) menyatakan bahwa reputasi KAP memiliki pengaruh negatif yang signifikan terhadap penerimaan opini audit going concern. 
Faktor selanjutnya yaitu opini audit tahun sebelumnya. Opini audit tahun sebelumnya dijadikan faktor yang mempengaruhi pemberian opini audit going concern oleh auditor. Ramadhany (2004) menemukan adanya hubungan positif antara opini audit going concern yang diterima tahun sebelumnya dengan opini audit going concern tahun berjalan. Apabila pada tahun sebelumnya auditor telah menerbitkan opini audit going concern, maka akan semakin besar kemungkinan auditor untuk menerbitkan kembali opini audit going concern pada tahun berikutnya.

Ramadhany (2004) mengungkapkan bahwa faktor ukuran perusahaan memiliki pengaruh negatif yang signifikan terhadap opini audit going concern. Penelitian tersebut membuktikan bahwa dengan ukuran perusahaan yang semakin besar maka perusahaan dapat menjamin kelangsungan usahanya, yang berarti kecil kemungkinan menerima opini audit going concern.

Faktor-faktor tersebut akan dijadikan variabel di dalam penelitian ini, diantaranya likuiditas, reputasi KAP, opini audit tahun sebelumnya, dan ukuran perusahaan. Adanya variabel yang sama seperti dengan penelitian sebelumnya bertujuan untuk menguji konsistensi hasil yang diperoleh oleh peneliti sebelumnya. Alasan dipilihnya perusahaan manufaktur karena perusahaan manufaktur umumnya memiliki jumlah aktiva tetap yang lebih besar dibandingkan jenis perusahaan lain, karena kegiatan usahanya membutuhkan berbagai alat untuk menunjang kegiatan produksi. Perusahaan yang memiliki aktiva tetap yang besar akan memiliki beban depresiasi yang besar pula, sehingga menimbulkan resiko yang cenderung besar, sedangkan alasan dipilihnya perusahaan yang mengalami financial distress karena auditor hampir tidak pernah mengeluarkan opini audit going concern pada perusahaan yang tidak mengalami financial distress (McKeown et al., 1991). Berdasarkan uraian di atas, maka peneliti tertarik untuk membahas pengaruh likuiditas, reputasi KAP, opini audit tahun sebelumnya, dan ukuran perusahaan terhadap penerimaan opini audit going concern pada perusahaan manufaktur yang mengalami financial distress di Bursa Efek Indonesia tahun 2014-2016.

Sesuai dengan rumusan masalah di atas, maka tujuan dari penelitian ini adalah menguji pengaruh likuiditas, reputasi KAP, opini audit tahun sebelumnya, dan ukuran perusahaan terhadap opini audit going concern pada perusahaan manufaktur yang terdaftar di Bursa Efek Indonesia.

\section{TINJAUAN PUSTAKA DAN PERUMUSAN HIPOTESIS}

\section{Landasan Teori}

\section{Teori keagenan (Agency theory)}

Menurut Anthony \& Govindarajan (2005), teori agensi adalah hubungan atau kontrak antara principal dan agent. Teori agensi memiliki asumsi bahwa tiap-tiap individu semata-mata 
termotivasi oleh kepentingan dirinya sendiri sehingga menimbulkan konflik kepentingan antara principal dan agent.

Agency theory menunjukkan bahwa perusahaan dapat dilihat sebagai suatu hubungan kontrak (loosely defined) antara pemegang sumber daya. Suatu hubungan agency muncul ketika satu atau lebih individu, yang disebut pelaku (principals), mempekerjakan satu atau lebih individu lain, yang disebut agen, untuk melakukan layanan tertentu dan kemudian mendelegasikan otoritas pengambilan keputusan kepada agen. Dalam kaitannya dengan penerimaan opini audit going concern, agen (manajemen) bertanggung jawab secara moral terhadap kelangsungan hidup perusahaan yang dipimpinnya. Pemilik memberi wewenang kepada agen untuk melakukan operasional perusahaan, sehingga informasi lebih banyak diketahui oleh agen dibandingkan pemilik. Baik prinsipal maupun agen diasumsikan orang ekonomi rasional dan semata-mata termotivasi oleh kepentingan pribadi. Agen mungkin akan takut mengungkapkan informasi yang tidak diharapkan oleh pemilik, sehingga terdapat kecenderungan untuk memanipulasi laporan keuangan tersebut. Maka dari itu diperlukan pihak ketiga yang independen yaitu auditor. Auditor dianggap mampu menghubungkan kepentingan pemilik (prinsipal) dan pihak agen (manajemen). Tugas dari auditor adalah memberikan jasa untuk menilai laporan keuangan yang dibuat oleh agen, mengenai kewajaran laporan keuangan tersebut. Auditor juga harus mempertimbangkan akan kelangsungan hidup perusahaan.

\section{Opini audit going concern}

Opini Audit Going Concern adalah opini audit yang dikeluarkan oleh auditor karena terdapat kesangsian besar mengenai kemampuan entitas dalam mempertahankan kelangsungan hidupnya (SPAP, 2011).

Menurut Standar Audit "SA" 570, penilaian manajemen atas kemampuan entitas untuk mempertahankan kelangsungan usahanya melibatkan suatu pertimbangan. Faktor-faktor berikut ini adalah relevan dengan pertimbangan tersebut :

1. Tingkat ketidakpastian yang berkaitan dengan hasil suatu peristiwa atau kondisi meningkatkan secara signifikan. Untuk alasan tersebut, kebanyakan kerangka pelaporan keuangan yang mencantumkan secara eksplisit adanya keharusan suatu penilaian oleh manajemen menyebutkan periode kapan manajemen diharuskan untuk mempertimbangkan seluruh informasi yang tersedia.

2. Ukuran dan kompleksitas entitas, sifat dan kondisi bisnisnya, serta tingkat keterpengaruhannya oleh faktor eksternal.

3. Setiap pertimbangan tentang masa depan didasarkan atas informasi yang tersedia ketika pertimbangan dilakukan. Peristiwa setelah tanggal pelaporan dapat menghasilkan keluaran yang tidak konsisten. 


\section{Kesulitan keuangan (financial distress)}

Financial distress terjadi ketika perusahaan mengalami kesulitan keuangan (financial difficult) yang dapat diakibatkan oleh bermacam-macam akibat. Salah satu penyebab kesulitan keuangan menurut Brigham \& Daves (2007) adalah adanya serangkaian kesalahan yang terjadi di dalam perusahaan, pengambilan keputusan yang kurang tepat oleh manajer, dan kelemahankelemahan yang saling berhubungan yang dapat menyumbang baik secara langsung maupun tidak langsung terhadap manajemen perusahaan, serta penyebab yang lain adalah kurangnya upaya pengawasan terhadap kondisi keuangan sehingga penggunaan dana perusahaan kurang sesuai dengan apa yang dibutuhkan. Hal ini memberikan kesimpulan bahwa tidak ada jaminan perusahaan besar dapat terhindar dari masalah ini, alasannya adalah karena financial distress berkaitan dengan kondisi keuangan perusahaan dimana setiap perusahaan pasti akan berurusan dengan keuangan untuk mencapai target laba dan kelangsungan hidup perusahaan.

Menurut Widyasaputri (2012), kondisi financial distress mempunyai arti bahwa perusahaan mengalami kondisi keuangan pada setiap tahunnya semakin menurun. Tata kelola yang buruk juga dapat menimbulkan perusahaan mengalami kesulitan keuangan karena adanya penyelewengan operasional perusahaan. Financial distress dapat terjadi karena adanya pengaruh dari dalam perusahaan (internal) dan dari luar perusahaan (eksternal). Faktor internal perusahaan meliputi :

1. Kesulitan arus kas perusahaan dapat terjadi karena kesalahan manajemen dalam mengelola arus kas untuk pembayaran aktivitas perusahaan dimana dapat memperburuk kondisi keuangan perusahaan.

2. Besarnya jumlah hutang timbul karena untuk menutupi biaya perusahaan yang terjadi, akibatnya menimbulkan kewajiban bagi perusahaan untuk mengembalikan hutang tersebut di masa depan.

3. Kerugian dari kegiatan operasi perusahaan selama beberapa tahun merupakan suatu akibat dari aktivitas perusahaan yang perlu diatasi dengan kebijakan tepat dalam jangka waktu singkat, kerugian operasi perusahaan dapat mengakibatkan arus kas negatif.

\section{Model prediksi kebangkrutan Altman}

Altman (1968) adalah orang yang pertama yang menerapkan multiple discriminant analysis. Analisa diskriminan ini merupakan suatu teknik statistik yang mengidentifikasikan beberapa macam rasio keuangan yang dianggap memiliki nilai paling penting dalam mempengaruhi suatu kejadian, lalu mengembangkannya dalam suatu model dengan maksud untuk memudahkan menarik kesimpulan dari suatu kejadian. 
Dengan berdasarkan penelitian analisa diskriminan, Altman melakukan penelitian untuk mengembangkan model baru untuk memprediksikan kebangkrutan perusahaan. Model yang dinamakan z-score dalam bentuk aslinya adalah model linier dengan rasio keuangan yang diberi bobot untuk memaksimalkan kemampuan model tersebut dalam memprediksi. Model ini pada dasarnya hendak mencari nilai "Z" yaitu nilai yang menunjukkan kondisi perusahaan, apakah dalam keadaan sehat atau tidak dan menunjukkan kinerja perusahaan yang sekaligus merefleksikan prospek perusahaan dimasa mendatang.

Setelah melakukan penelitian terhadap variabel dan sampel yang dipilih, Altman menghasilkan model kebangkrutan yang pertama. Persamaan kebangkrutan yang ditujukan untuk memprediksi sebuah perusahaan publik manufaktur. Persamaan dari model Altman pertama yaitu :

$Z=1,2 X_{1}+1,4 X_{2}+3,3 X_{3}+0,6 X_{4}+0,999 X_{5}$

Keterangan :

Z = bankrupcy index

$X_{1} \quad=$ working capital $/$ total asset

$X_{2} \quad=$ retained earnings $/$ total asset

$X_{3} \quad=$ earnings before interest and taxes $/$ total asset

$X_{4}=$ market value of equity / book value of total debt

$X_{5} \quad=$ sales $/$ total asset

Nilai $\mathrm{Z}$ adalah indeks keseluruhan fungsi multiple discriminant analysis. Menurut Altman, terdapat angka-angka cut off nilai Z yang dapat menjelaskan apakah perusahaan akan mengalami kegagalan atau tidak pada masa mendatang dan ia membaginya ke dalam tiga kategori, yaitu sebagai berikut :

1. Jika nilai $\mathrm{Z}<1,8$, maka termasuk perusahaan yang bangkrut.

2. Jika nilai $1,8<\mathrm{Z}<2,99$, maka termasuk ke dalam grey area (tidak dapat ditentukan apakah perusahaan sehat atau mengalami kebangkrutan).

3. Jika nilai $\mathrm{Z}>2,99$ maka termasuk perusahaan yang tidak bangkrut.

Model yang dikembangkan oleh Altman ini mengalami revisi. Revisi tersebut merupakan penyesuaian agar model prediksi kebangkrutan tidak hanya untuk perusahaan manufaktur yang go public melainkan juga dapat diterapkan pada perusahaan-perusahaan swasta. Altman mengubah variabel market value of equity menjadi book value of equity pada X4 karena perusahaan privat tidak memiliki harga pasar untuk ekuitasnya. Persamaan dari model Altman revisi (1983) adalah sebagai berikut :

$Z=0,717 X_{1}+0,847 X_{2}+3,108 X_{3}+0,42 X_{4}+0,988 X_{5}$

Keterangan :

Z $\quad$ = bankrupcy index 


$$
\begin{array}{ll}
X_{1} & =\text { working capital / total asset } \\
X_{2} & =\text { retained earnings / total asset } \\
X_{3} & =\text { earnings before interest and taxes / total asset } \\
X_{4} & =\text { book value of equity / book value of total debt } \\
X_{5} & =\text { sales / total asset }
\end{array}
$$

Klasifikasi perusahaan yang sehat dan bangkrut dari model Altman Revisi ini adalah sebagai berikut :

1. Jika nilai $\mathrm{Z}<1,23$, maka termasuk perusahaan yang bangkrut.

2. Jika nilai $1,23<\mathrm{Z}<2,9$, maka termasuk ke dalam grey area (tidak dapat ditentukan apakah perusahaan sehat atau mengalami kebangkrutan).

3. Jika nilai $\mathrm{Z}>2,9$ maka termasuk perusahaan yang tidak bangkrut.

Seiring berjalannya waktu, Altman memodifikasi modelnya supaya dapat diterapkan pada semua perusahaan, seperti manufaktur, non manufaktur, dan perusahaan penerbit obligasi di negara berkembang. Dalam model ini, Altman mengeliminasi variabel X5 (sales/total asset), karena rasio ini sangat bervariatif pada industry dengan ukuran aset yang berbeda-beda.

Persamaan Z-Score Altman Modifikasi (1995) adalah sebagai berikut :

$Z=6,56 X_{1}+3,26 X_{2}+6,72 X_{3}+1,05 X_{4}$

Keterangan :

$$
\begin{array}{ll}
Z & =\text { bankrupcy index } \\
X_{1} & =\text { working capital / total asset } \\
X_{2} & =\text { retained earnings / total asset } \\
X_{3} & =\text { earnings before interest and taxes / total asset } \\
X_{4} & =\text { book value of equity / book value of total debt }
\end{array}
$$

Klasifikasi perusahaan yang sehat dan bangkrut dari model Altman Modifikasi ini adalah sebagai berikut :

1. Jika nilai $\mathrm{Z}<1,1$, maka termasuk perusahaan yang bangkrut.

2. Jika nilai $1,1<\mathrm{Z}<2,6$, maka termasuk ke dalam grey area (tidak dapat ditentukan apakah perusahaan sehat atau mengalami kebangkrutan).

3. Jika nilai $\mathrm{Z}>2,6$ maka termasuk perusahaan yang tidak bangkrut.

\section{Likuiditas}

Likuiditas merupakan suatu cara yang digunakan dalam menguji tingkat proteksi yang diperoleh pemberi pinjaman berpusat pada kredit jangka pendek yang diberikan kepada perusahaan untuk mendanai operasi perusahaan. Hal ini mencakup aktiva likuid perusahaan. Aktiva likuid merupakan aktiva lancar yang dapat segera dikonversikan menjadi kas, dengan asumsi aktiva ini dapat menjadi pelindung dalam menghadapi kegagalan. Likuiditas adalah 
kemampuan aktiva lancar perusahaan dalam memenuhi kewajiban jangka pendek dengan aktiva lancar yang dimiliki (Darsono \& Ashari, 2004).

Pengukuran tingkat likuiditas perusahaan dilakukan dengan menggunakan rasio lancar atau current ratio. Current ratio merupakan rasio yang menunjukan sejauh mana aktiva lancar menutupi kewajiban-kewajiban lancar. Semakin besar perbandingan aktiva lancar dengan utang lancar semakin tinggi kemampuan perusahaan menutupi kewajiban jangka pendeknya (Harahap, 2011: 301). Rumus current ratio adalah sebagai berikut :

$$
\text { Rasio Lancar }=\frac{\text { Aktiva Lancar }}{\text { Kewajiban Lancar }} \ldots
$$

Perusahaan yang memiliki rasio lancar tinggi, maka perusahaan tersebut dianggap memiliki kemampuan untuk membayar kewajiban jangka pendeknya dan mempertahankan kelangsungan usaha. Semakin rendah rasio lancar, maka perusahaan dikhawatirkan tidak dapat memenuhi kewajibannya terhadap pihak yang bersangkutan. Dari sudut pandang pemberi pinjaman, suatu rasio yang lebih tinggi tampaknya dapat memberikan perlindungan terhadap kemungkinan kerugian bila terjadi kegagalan perusahaan.

\section{Reputasi KAP}

Tanggung jawab KAP khususnya auditor adalah menyediakan informasi yang memadai dengan kualitas tinggi guna pengambilan keputusan oleh para pengguna. KAP yang memiliki kualitas lebih tinggi cenderung akan mengeluarkan opini audit going concern apabila terdapat masalah going concern pada klien (Santosa \& Wedari, 2007). Kualitas KAP sering diproksikan dengan reputasi KAP. KAP diklasifikasikan menjadi dua yakni KAP big four dan KAP non big four. KAP big four dianggap memiliki kemampuan yang lebih baik dalam mengaudit dibandingkan dengan KAP non big four. KAP big four ini akan berafiliasi dengan kantor akuntan publik lokal yang ada di Indonesia. KAP big four beserta afiliasinya terdiri atas :

1. Ernst \& Young berafiliasi dengan KAP Purwantono, Suherman dan Surja.

2. Deloitte Touche Tohmatsu berafiliasi dengan KAP Osman Bing Satrio.

3. KPMG berafiliasi dengan KAP Sidharta dan Widjaja.

4. Price Waterhouse Coopers berafiliasi dengan KAP Tanudiredja, Wibisana dan Rekan.

\section{Opini audit tahun sebelumnya}

Opini audit tahun sebelumnya adalah opini audit yang diterima oleh perusahaan pada tahun sebelumnya atau 1 tahun sebelum penelitian. Opini audit ini dibedakan menjadi dua yaitu opini audit going concern dan opini audit non going concern. Opini audit tahun sebelumnya memiliki pengaruh terhadap penerimaan opini audit going concern. Perusahaan yang telah 
menerima opini audit going concern pada tahun sebelumnya dianggap memiliki masalah dalam mempertahankan kelangsungan hidupnya, sehingga kemungkinan besar auditor akan memberikan opini audit going concern kembali pada tahun berjalan (Santosa \& Wedari, 2007).

\section{Ukuran perusahaan}

Ukuran perusahaan bisa diukur dengan menggunakan total aset, penjualan, atau modal dari perusahaan tersebut. Salah satu tolak ukur yang menunjukkan besar kecilnya perusahaan adalah ukuran aset dari perusahaan. Perusahaan yang memiliki total aset besar menunjukkan bahwa perusahaan tersebut telah mencapai tahap kedewasaan. Pada tahap ini arus kas perusahaan sudah positif dan dianggap memiliki prospek yang baik dalam jangka waktu yang relatif lama, selain itu juga mencerminkan bahwa perusahaan relatif lebih stabil dan lebih mampu menghasilkan laba dibandingkan perusahaan dengan total aset yang kecil.

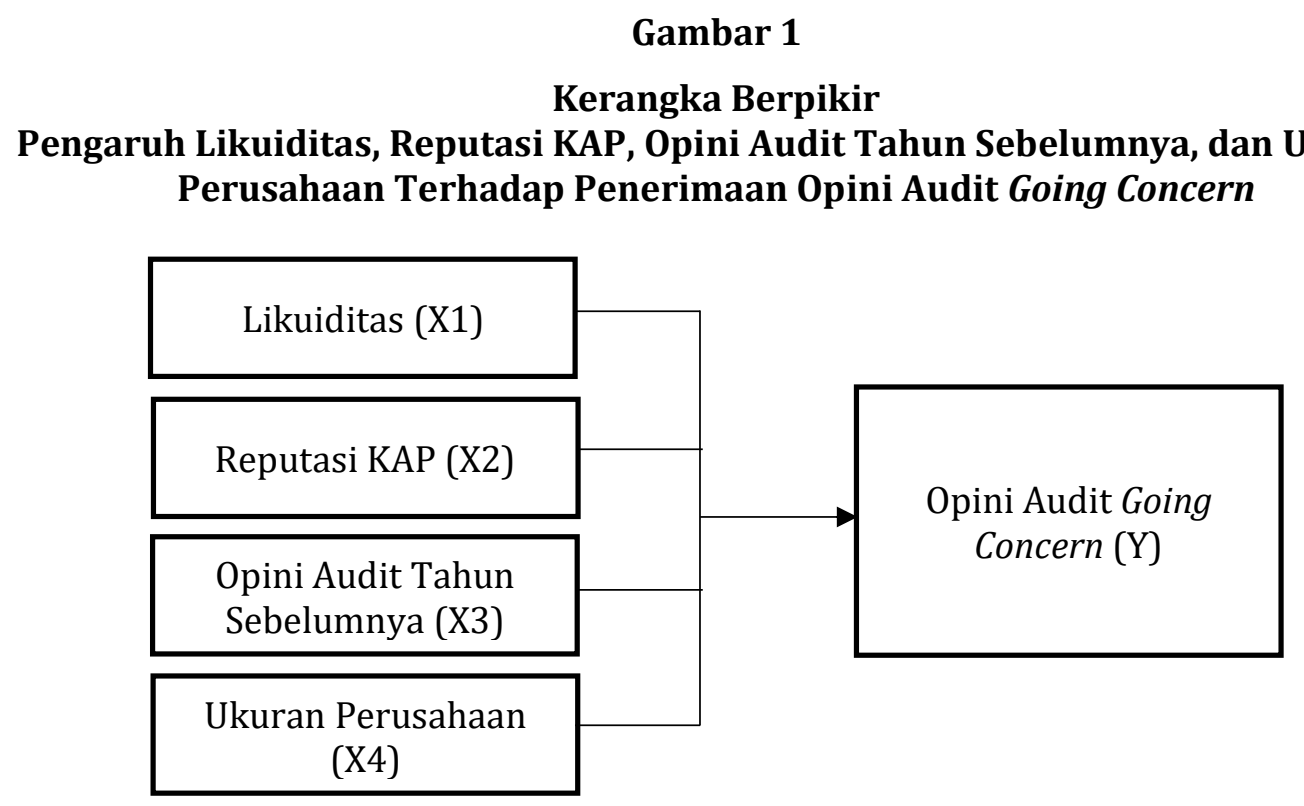

Sumber: Hasil pemikiran peneliti (2018)

\section{Hipotesis}

1) Pengaruh likuiditas terhadap penerimaan opini audit going concern

Likuiditas merupakan kemampuan perusahaan dalam membayar kewajiban-kewajiban jangka pendeknya dengan menggunakan aktiva lancar yang dimiliki. Dalam hubungannya dengan likuiditas makin kecil likuiditas, perusahaan kurang likuid sehingga tidak dapat membayar para krediturnya maka auditor kemungkinan memberikan opini audit dengan going concern. Tidak jarang perusahaan yang secara konsisten mengalami kerugian operasi mempunyai working capital yang sangat kecil bila dibandingkan dengan total aset (Altman, 1968). Kemampuan 
perusahaan yang rendah dalam melaksanakan kewajibannya akan menyebabkan auditor ragu akan kelangsungan hidup perusahaan tersebut. Keraguan auditor akan menyebabkan penerimaan opini audit going concern terhadap perusahaan Januarti \& Fitrianasari (2008). Dari hasil penelitian, Kristiana (2012) dan Januarti \& Fitrianasari (2008) menyatakan bahwa likuiditas berpengaruh negatif terhadap opini audit going concern

H1: Likuiditas berpengaruh negatif terhadap penerimaan opini audit going concern.

2) Pengaruh reputasi KAP terhadap terhadap penerimaan opini audit going concern

Reputasi KAP menunjukkan prestasi dan kepercayaan publik yang disandang auditor atas nama besar yang dimiliki auditor (Rudyawan \& Badera, 2009). KAP dengan reputasi big four dianggap perusahaan memiliki kualitas audit yang lebih baik dibandingkan dengan KAP non big four. KAP dengan reputasi yang lebih baik akan cenderung memberikan opini audit going concern jika perusahaan memiliki masalah yang berkaitan dengan kelangsungan usahanya. KAP non big four memiliki reputasi yang lebih rendah dari KAP big four sehingga kualitas audit yang diberikan pun akan lebih rendah.

H2: Reputasi KAP berpengaruh positif terhadap penerimaan opini audit going concern.

3) Pengaruh opini audit tahun sebelumnya terhadap penerimaan opini audit going concern

Opini audit going concern tahun sebelumnya dapat menjadi bahan pertimbangan yang penting bagi auditor untuk mengeluarkan kembali opini audit going concern pada tahun berikutnya. Dalam penelitian yang dilakukan Santosa \& Wedari (2007) memberikan bukti bahwa setelah auditor mengeluarkan opini going concern, perusahaan harus menunjukkan peningkatan keuangan yang signifikan untuk memperoleh opini bersih di tahun berikutnya, jika perusahaan tidak mengalami peningkatan keuangan maka perusahaan dapat menerima kembali opini going concern. Hal ini sejalan dengan penelitian Ramadhany (2004) yang menunjukkan bukti bahwa opini audit tahun sebelumya berpengaruh positif terhadap penerimaan opini audit going concern. Sehingga apabila auditor menerbitkan opini audit going concern tahun sebelumnya maka akan semakin besar kemungkinan perusahaan akan menerima opini audit going concern pada tahun berjalan (Santosa \& Wedari, 2007).

H3: Opini audit tahun sebelumnya berpengaruh positif terhadap penerimaan opini audit going concern.

4) Pengaruh ukuran perusahaan terhadap penerimaan opini audit going concern

Ukuran perusahaan yang diproksikan dengan total aset yang dimiliki menunjukkan kemampuan perusahaan dalam menjaga kelangsungan usaha. Semakin tinggi total aset yang dimiliki, maka perusahaan dianggap memiliki ukuran yang besar sehingga mampu 
mempertahankan kelangsungan usahanya. Perusahaan besar memiliki kemampuan yang lebih baik dalam mengelola perusahaan dan menghasilkan laporan keuangan yang lebih berkualitas Junaidi \& Hartono (2010). Semakin kecil skala perusahaan menunjukkan kemampuan perusahaan yang lebih kecil dalam pengelolaan usahanya. Hal ini menyebabkan perusahaan lebih berpeluang mendapatkan opini audit going concern.

H4: Ukuran perusahaan berpengaruh negatif terhadap penerimaa opini deaudit going concern.

\section{METODE PENELITIAN}

\section{Populasi dan Sampel}

Populasi dalam penelitian ini adalah perusahaan yang mengalami kesulitan keuangan (financial distress) yang terdaftar di Bursa Efek Indonesia periode 2014-2016. Alasan dipilihnya perusahaan manufaktur karena perusahaan manufaktur memiliki proporsi aktiva tetap yang lebih besar dibandingkan perusahaan lain, karena kegiatan usahanya membutuhkan berbagai alat untuk menunjang kegiatan produksi. Perusahaan yang memiliki aktiva tetap yang besar akan memiliki beban depresiasi yang besar pula, sehingga menimbulkan resiko usaha, sedangkan alasan dipilihnya perusahaan yang mengalami financial distress, karena auditor hampir tidak pernah mengeluarkan opini audit going concern pada perusahaan yang tidak mengalami financial distress (McKeown et al., 1991).

Untuk menentukan perusahaan tersebut tergolong ke dalam financial distress adalah dengan menggunakan model prediksi kebangkrutan Altman ZScore Modifikasi (1995). Dari nilai hitung ZScore, diambil perusahaan yang mengalami financial distress atau yang berada pada grey area pada tahun pengamatan.

Sampel perusahaan manufaktur yang digunakan dalam penelitian ini dipilih dengan metode purposive sampling dari seluruh perusahaan manufaktur yang terdaftar di Bursa Efek Indonesia (BEI) pada tahun 2014-2016. Proses pengambilan sampel dengan metode purposive sampling dan berikut hasil seleksi dari populasi tersebut :

Tabel 1

Purposive Sampling

\begin{tabular}{clc}
\hline No & \multicolumn{1}{c}{ Kriteria } & Jumlah \\
\hline 1 & $\begin{array}{l}\text { Perusahaan manufaktur yang terdaftar di Bursa } \\
\text { Efek Indonesia } \\
\text { Tidak terdaftar berturut-turut dari tahun 2013- }\end{array}$ & 144 \\
2 & $\begin{array}{l}\text { 2016 } \\
\text { Tidak menyajikan laporan keuangan yang telah } \\
\text { diaudit dalam nilai mata uang Rupiah. }\end{array}$ \\
& $\begin{array}{l}\text { Perusahaan tidak berada pada grey area atau } \\
\text { mengalami financial distress pada tahun } \\
\text { pengamatan }\end{array}$
\end{tabular}


5 Tidak terdapat laporan auditor independen

Jumlah Sampel

Tahun Pengamatan ( $3 \times 31$ )

Sumber: Data diolah (2018)
(2)

31

93

Tabel 2

Definisi Operasional Variabel

Variabel

Likuiditas (X1)

Reputasi KAP (X2)

Opini Audit Tahun

Sebelumnya (X3)

Ukuran perusahaan (X4)

Opini Audit Going Concern (Y)
Pengukuran tingkat likuiditas perusahaan dilakukan dengan menggunakan rasio lancar atau current ratio. Current ratio merupakan rasio yang menunjukan sejauh mana aktiva lancar menutupi kewajiban-kewajiban lancar.

Kualitas KAP sering diproksikan dengan reputasi KAP. KAP diklasifikasikan menjadi dua yakni KAP big four dan KAP non big four. Kode 1 diberikan untuk perusahaan yang menggunakan jasa KAP big four, sedangkan kode 0 untuk perusahaan yang menggunakan jasa KAP non big four.

Opini audit tahun sebelumnya adalah opini audit yang dikeluarkan oleh auditor independen pada tahun sebelumnya. Variabel ini merupakan jenis opini going concern. Kode 1 diberikan untuk perusahaan yang mendapatkan opini going concern pada tahun sebelumnya, sedangkan kode 0 untuk perusahaan yang tidak mendapatkan opini going concern.

Ukuran perusahaan adalah kondisi keuangan yang dimiliki oleh perusahaan. Proksi yang digunakan dalam menilai kondisi keuangan perusahaan adalah $\log \mathrm{n}$ dari total aset yang dimiliki.

Opini audit going concern adalah opini audit yang dikeluarkan oleh auditor karena terdapat kesangsian besar mengenai kemampuan entitas dalam mempertahankan kelangsungan hidupnya (SPAP, 2011). Opini audit going concern diberi kode 1 , sedangkan untuk opini audit non going concern diberi kode 0 . 
Penelitian ini menggunakan metode pengumpulan data yang dilakukan dengan mengumpulkan data yang dibutuhkan dalam penelitian antara lain adalah melakukan dokumentasi dan mencari data langsung dari catatan-catatan atau dokumen-dokumen perusahaan sesuai dengan data yang diperlukan. Data sekunder yang dibutuhkan terdiri dari laporan keuangan perusahaan maupun laporan tahunan perusahaan yang diterbitkan oleh perusahaan manufaktur yang listing di BEI dan sesuai dengan kriteria pemilihan sampel.

\section{Teknik Analisis Data}

Analisis data mempunyai tujuan untuk menyampaikan dan membatasi penemuanpenemuan hingga menjadi data yang teratur. Semua data terkumpul dan relevan dikelompokkan kedalam sub-sub bagian dari masing-masing variabel. Data kuantitatif disajikan dalam bentuk diskriptif. Semua data yang dikumpulkan akan dianalisis tentang hubungan dan pengaruh antara variabel. Sesuai dengan hipotesis yang telah dirumuskan maka analisis yang digunakan adalah analisis regresi logistik. Tujuannya untuk menetapkan seberapa baik model yang digunakan cocok untuk menguji hipotesis yang telah dirumuskan.

\section{Statistik deskriptif}

Analisis statistik deskriptif digunakan untuk mengetahui karakteristik sampel yang digunakan dan menggambarkan variabel-variabel dalam penelitian. Analisis deskriptif meliputi jumlah sampel, nilai minimum dan nilai maksimum.

\section{Uji multikolinearitas}

Uji multikolinearitas bertujuan untuk menguji apakah model regresi ditemukan adanya korelasi antar variabel independen. Model regresi yang baik adalah regresi dengan tidak adanya gejala korelasi yang kuat di antara variabel bebasnya. Pengujian ini menggunakan matrik korelasi antar variabel bebas untuk melihat besarnya korelasi antar variabel independen. Jika terdapat koefisien korelasi sederhana yang mencapai atau melebihi 0,8 maka hal tersebut menunjukkan terjadinya multikolinearitas dalam regresi.

\section{Analisis regresi logistik (logistic regression)}

Analisis regresi logistik merupakan bentuk pengujian apakah probabilitas terjadinya variabel dependen dapat diprediksi dengan variabel independennya. Persamaan regresi logistik dengan menggunakan standardized coefficients :

$$
\operatorname{Ln} \frac{G C}{1-G C}=\alpha+\beta_{1} L K+\beta_{2} K A P+\beta_{3} O P I N I+\beta_{4} S I Z E+\varepsilon \ldots \ldots . . .(3)
$$


Keterangan :

$\begin{array}{ll}\operatorname{Ln} \frac{G C}{1-G C} & \text { : Opini going concern (1 untuk opini going concern, dan } 0 \text { untuk opini non } \\ \text { going concern). } & \\ \alpha & : \text { Konstanta } \\ \beta 1-\beta 6 & : \text { Koefisien regresi } \\ \text { LK } & : \text { Likuiditas } \\ \text { KAP } & : \text { Reputasi KAP (1 untuk KAP big four, dan } 0 \text { untuk KAP non big four). } \\ \text { OPINI } & : \text { Opini audit tahun sebelumnya (1 jika opini GC, dan } 0 \text { opini NGC) } \\ \text { SIZE } & : \text { Ukuran perusahaan, dihitung dari total aset. } \\ \varepsilon & : \text { error }\end{array}$

\section{Uji kelayakan model regresi (omnibus test)}

Pengujian Omnibus of model coefficients digunakan untuk mengetahui apakah semua variabel independen secara bersama-sama dapat memprediksi variabel dependen atau tidak. Kelayakan model regresi dinilai dengan menggunakan Hosmer and Lemeshow's Goodness of fit test. Jika nilai statistik Hosmer and Lemeshow Goodness of fit lebih besar daripada 0,05 maka hipotesis 0 tidak dapat ditolak dan berarti model mampu memprediksi nilai observasinya atau dapat dikatakan model dapat diterima karena sesuai dengan data observasinya (Ghozali, 2016)

\section{Koefisien determinasi (nagelkerke R square)}

Nagelkerke R Square merupakan ukuran yang yang dilakukan untuk mengetahui seberapa besar variabel independen mampu menjelaskan dan mempengaruhi variabel dependen. Nilai Nagelkerke R Square nilainya bervariasi antara 0 (nol) sampai 1 (satu). Semakin mendekati nilai 1 maka model dianggap semakin goodness of fit sementara semakin mendekati 0 maka model dianggap semakin tidak goodness of fit (Ghozali, 2016: 329).

\section{Menilai model fit (overall model fit test)}

Untuk menilai keseluruhan model (overall model fit) yang telah dihipotesiskan telah fit atau tidak dengan data, maka perlu dilakukan uji ini. Hipotesis untuk menilai model fit adalah: H0 : Model yang dihipotesiskan fit dengan data H1 : Model yang dihipotesiskan tidak fit dengan data Dari hipotesis ini jelas bahwa kita tidak dapat menolak hipotesis nol agar supaya model fit dengan data. Statistik yang digunakan berdasarkan Likelihood. Likelihood dari model adalah probabilitas bahwa model yang dihipotesiskan menggambarkan data input. Log Likelihood pada regresi logistik mirip dengan pengertian "Sum of Square Error" pada model regresi, sehingga penurunan model Log Likelihood menunjukkan model regresi yang semakin baik (Ghozali, 2016: 328). 


\section{Matriks klasifikasi}

Matriks klasifikasi menunjukkan kekuatan prediksi dari model regresi untuk memprediksi kemungkinan penerimaan opini audit going concern pada perusahaan manufaktur.

\section{HASIL DAN PEMBAHASAN}

Obyek penelitian yang digunakan dalam penelitian ini yaitu perusahaan manufaktur yang mengalami financial distress di Bursa Efek Indonesia tahun 2014-2016. Alasan dipilihnya perusahaan manufaktur karena perusahaan manufaktur umumnya memiliki jumlah aktiva tetap yang lebih besar dibandingkan jenis perusahaan lain, karena kegiatan usahanya membutuhkan berbagai alat untuk menunjang kegiatan produksi. Perusahaan yang memiliki aktiva tetap yang besar akan memiliki beban depresiasi yang besar pula, sehingga menimbulkan resiko yang cenderung besar, sedangkan alasan dipilihnya perusahaan yang mengalami financial distress karena auditor hampir tidak pernah mengeluarkan opini audit going concern pada perusahaan yang tidak mengalami financial distress (McKeown et al., 1991). Jumlah perusahaan yang terdaftar berturut-turut pada periode tersebut adalah 126 perusahaan. Proses seleksi sampel berdasarkan kriteria yang ditetapkan telah disajikan pada table 3. Dari proses seleksi tersebut, terdapat 18 perusahaan yang tidak terdaftar berturut-turut dari tahun 2013-2016, terdapat 26 perusahaan yang tidak menyajikan laporan keuangan dengan nilai mata uang rupiah, terdapat 67 perusahaan yang tidak berada pada grey area dan financial distress selama tahun pengamatan atau tergolong ke perusahaan sehat, dan terdapat 2 perusahaan yang tidak mempunyai laporan auditor independen pada laporan keuangannya.

Berdasarkan kriteria sampel tersebut, diperoleh sebanyak 93 sampel selama periode penelitian tahun 2014-2016, dan selanjutnya dikelompokkan berdasarkan opini audit yang diterima, yaitu opini going concern (GC) atau opini non going concern (NonGC). Pengelompokkan tersebut disajikan pada tabel di bawah ini :

Tabel 3

Pengelompokkan Auditee Berdasarkan Opini Audit yang Diterima

\begin{tabular}{ccccc}
\hline \multirow{2}{*}{ Opini } & \multicolumn{3}{c}{ Auditee } & \multirow{2}{*}{ Total } \\
\cline { 2 - 4 } & $\mathbf{2 0 1 4}$ & $\mathbf{2 0 1 5}$ & $\mathbf{2 0 1 6}$ & \\
\hline GC & 4 & 4 & 6 & 14 \\
Non GC & 27 & 27 & 25 & 79 \\
\hline Total & 31 & 31 & 31 & 93 \\
\hline
\end{tabular}

Sumber: Data diolah (2018)

\section{Analisis statistik deskriptif}

Hasil pengujian dengan statistik deskriptif disajikan dalam tabel 5.2. 
Tabel 4

Hasil Uji Statistik Deskriptif

\begin{tabular}{llrrrr}
\hline & N & Minimum & Maximum & \multicolumn{1}{l}{ Mean } & \multicolumn{1}{l}{ Std.Deviation } \\
LK & 93 & .20 & 2.52 & 1.0912 & .39415 \\
KAP & 93 & .00 & 1.00 & .2581 & .43994 \\
OPINI & 93 & .00 & 1.00 & .1398 & .34864 \\
SIZE & 93 & 25.25 & 33.20 & 28.2589 & 1.72206 \\
GC & 93 & .00 & 1.00 & .1505 & .35954 \\
Valid N & 93 & & & & \\
(listwise) & & & & & \\
\hline
\end{tabular}

Hasil uji statistik deskriptif pada Tabel 4 menunjukkan nilai minimum, nilai maksimum, nilai rata-rata (mean), dan standar deviasi pada masing-masing variabel. Berdasarkan Tabel 5.2, dapat diketahui bahwa :

1. Variabel likuiditas (LK) memiliki nilai minimum 0,20 dan nilai maksimum 2,52, dengan nilai mean 1,0912 dan standar deviasi 0,39415. Nilai mean sebesar 1,0912 atau 109,12\% yang artinya rata-rata perusahaan sampel memiliki kemampuan untuk membayar kewajiban jangka pendeknya.

2. Variabel reputasi KAP (KAP) memiliki nilai minimum 0,00 dan nilai maksimum 1,00, dengan nilai mean 0,2581 dan standar deviasi 0,43994. Nilai mean sebesar 0,2581 yang lebih kecil dari 0,50 menunjukkan bahwa rata-rata perusahaan sampel menggunakan KAP non big four.

3. Variabel opini audit tahun sebelumnya (OPINI) memiliki nilai minimum 0,00 dan nilai maksimum 1,00, dengan nilai mean 0,1398 dan standar deviasi 0,34864. Nilai mean sebesar 0,1398 yang lebih kecil dari 0,50 menunjukkan bahwa rata-rata perusahaan sampel tidak mendapatkan opini going concern pada tahun sebelumnya.

4. Variabel ukuran perusahaan (SIZE) memiliki nilai minimum 25,25 dan nilai maksimum 33,20 , dengan nilai mean 28,2589 dan standar deviasi 1,72206. Nilai mean sebesar 28,2589 yang cenderung mendekati nilai minimum menunjukkan bahwa rata-rata perusahaan sampel tergolong ke perusahaan kecil.

\section{Uji multikolinearitas}

Model regresi yang baik adalah regresi dengan tidak adanya gejala korelasi yang kuat di antara variabel bebasnya. Pengujian ini menggunakan matriks korelasi antar variabel bebas untuk melihat besarnya korelasi antar variabel independen. 
Tabel 5

Hasil Uji Multikolinearitas

Correlation Matrix

\begin{tabular}{rlllll}
\hline & Constant & LK & KAP & OPINI & SIZE \\
Step1 Constant & 1.000 & -.037 & .000 & -.403 & -.9997 \\
LK & -.037 & 1.000 & .000 & -.591 & -.034 \\
KAP & .000 & .000 & 1.000 & .000 & .000 \\
OPINI & -.403 & -.591 & .000 & 1.000 & .430 \\
SIZE & -.997 & -.034 & .000 & .430 & 1.000 \\
\hline
\end{tabular}

Berdasarkan tabel di atas, nilai koefisien korelasi antara variabel bebas tidak ada yang lebih dari 0,8 , sehingga menunjukkan bahwa tidak terdapat gejala multikolinearitas antara variabel bebas.

\section{Analisis regresi logistik}

Analisis data dalam penelitian ini dilakukan menggunakan regresi logistik. Regresi logistik digunakan untuk menguji apakah probabilitas terjadinya variabel terikat dapat diprediksi dengan variabel bebasnya (Ghozali, 2016). Regresi logistik digunakan dalam penelitian ini karena variabel terikatnya merupakan variabel dummy.

\section{Uji kelayakan model regresi (omnibus test)}

Uji kelayakan model regresi dinilai dengan menggunakan Hosmer and Lemeshow's Goodness of Fit Test. Hasil dari uji kelayakan model regresi dapat dilihat pada Tabel 6 di bawah ini.

Tabel 6

Hasil Uji Kelayakan Model Regresi

Hosmer and Lemeshow Test

\begin{tabular}{lrrr}
\hline Step & Chi-suare & df & \multicolumn{1}{l}{ Sig. } \\
1 & 9.414 & 8 & .309 \\
\hline
\end{tabular}

Berdasarkan hasil uji pada tabel di atas, menunjukkan bahwa nilai chi-square sebesar 9,414 dengan nilai signifikansi sebesar 0,309. Nilai signifikansi $>0,05$ yang berarti model regresi yang terbentuk mampu memprediksi nilai observasi dengan baik dan cocok dengan data observasinya, sehingga model regresi yang dipergunakan dalam penelitian ini layak dipakai untuk analisis selanjutnya. 


\section{Koefisien determinasi (nagelkerke R square)}

Untuk menilai koefisien determinasi pada model regresi logistik ditunjukkan oleh nilai Nagelkerke R Square. Uji ini bertujuan untuk mengetahui seberapa besar variabel dependen dapat dijelaskan oleh variabel independen. Hasil dari uji koefisien determinasi dapat dilihat pada Tabel 5.5 di bawah ini.

Tabel 7

Hasil Uji Koefisien Determinasi (Nagelkerke R Square)

Model Summary

\begin{tabular}{llll}
\hline Step & -2 Log likehood & Cox \& Snell R Square & Negelkerke R Square \\
1 & 31.618 & .398 & .696 \\
\hline
\end{tabular}

a. Estimation terminated at iteration number 20 because maximum iteration has been reached. Final solution cannot be found.

Nilai Nagelkerke R Square pada tabel di atas sebesar 0,696 yang berarti bahwa variansi variabel opini going concern yang dapat dijelaskan oleh variabel LK, KAP, OPINI, dan SIZE adalah sebesar $69,6 \%$, sedangkan sisanya sebesar 30,4\% dipengaruhi oleh faktor-faktor lain di luar variabel tersebut.

\section{Menilai model fit (overall model fit test)}

Menilai keseluruhan model dapat dilakukan dengan memperhatikan angka Log Likelihood (LL) yaitu -2LL awal (block number=0) dan -2LL akhir (block number=1). Keseluruhan model ini dapat dikatakan baik apabila terjadi penurunan antara -2LL awal dan -2LL akhir. Perbandingan hasil overall model fit test ditunjukkan pada Tabel 5.6 di bawah ini.

Tabel 7

Perbandingan Nilai -2Log Likelihood

\begin{tabular}{cc}
\hline -2LL awal (Block number $=0$ ) & 78,797 \\
-2LL akhir (Block number $=1)$ & 31,618 \\
Penurunan -2LL & 47,179 \\
\hline
\end{tabular}

Sumber: Data diolah (2018)

Berdasarkan Tabel 7, dapat diketahui bahwa nilai -2LL awal sebesar 78,797, sedangkan nilai -2LL akhir sebesar 31,618. Adapun penurunan angka dari -2LL awal ke -2LL akhir adalah sebesar 47,179 yang menunjukkan penambahan variabel bebas ke dalam model dapat memperbaiki model fit serta menunjukkan model regresi yang lebih baik. 


\section{Matriks klasifikasi}

Matriks klasifikasi menunjukkan kekuatan prediksi dari model regresi untuk memprediksi penerimaan opini audit going concern oleh perusahaan. Hasil pengujian ini dapat dilihat pada Tabel 5.7 di bawah ini.

Tabel 8

Matriks Klasifikasi

Classification Table ${ }^{3}$

\begin{tabular}{|c|c|c|c|c|}
\hline & \multirow[b]{3}{*}{ Obsened } & \multicolumn{3}{|c|}{ Predicted } \\
\hline & & \multicolumn{2}{|c|}{$\mathrm{GC}$} & \multirow[b]{2}{*}{$\begin{array}{c}\text { Percentage } \\
\text { Correct } \\
\end{array}$} \\
\hline & & 0 & 1 & \\
\hline \multirow[t]{3}{*}{ Step 1} & GC $\quad 0$ & 77 & 2 & 97.5 \\
\hline & 1 & 4 & 10 & 71.4 \\
\hline & Overall Percentage & & & 93.5 \\
\hline
\end{tabular}

a. The cut value is .500

Berdasarkan hasil pengujian Tabel 8 di atas, kekuatan prediksi dari model regresi untuk memprediksi kemungkinan perusahaan menerima opini audit going concern adalah sebesar $71,4 \%$. Hal ini menunjukkan bahwa dengan menggunakan model regresi tersebut, terdapat sebanyak 10 perusahaan yang akan menerima opini audit going concern dari total 14 perusahaan yang menerima opini audit going concern, sedangkan kekuatan prediksi dari model regresi untuk memprediksi kemungkinan perusahaan menerima opini audit non going concern adalah sebesar 97,5\%. Hal ini menunjukkan bahwa dengan menggunakan model regresi tersebut, terdapat 77 perusahaan yang menerima opini audit non going concern dari total 79 perusahaan yang menerima opini audit non going concern.

\section{Model regresi yang terbentuk}

Hasil uji regresi yang terbentuk dilihat dari Tabel 5.8 di bawah ini.

Tabel 9

Model Regresi yang Terbentuk

Variables in the Equation

\begin{tabular}{llllllll}
\hline & & B & S.E. & Wald & Df & Sig. & Exp(B) \\
Step1 ${ }^{\mathrm{a}}$ & LK & -1.562 & 1.097 & 2.027 & 1 & .155 & .210 \\
& KAP & -19.116 & $8.059 \mathrm{E} 3$ & .000 & 1 & .998 & .000 \\
& OPINI & 5.628 & 1.503 & 14.016 & 1 & .000 & 278.122 \\
& SIZE & .312 & .533 & .343 & 1 & .558 & 1.366
\end{tabular}


Tabel 9 di atas menunjukkan hasil pengujian dengan regresi logistik pada tingkat kesalahan 5\%. Hasil pengujian regresi logistik tersebut menghasilkan model regresi sebagai berikut :

$$
\begin{aligned}
\operatorname{Ln} \frac{G C}{1-G C}=- & 9,944-1,562 L K-19,116 K A P+5,628 \text { OPINI } \\
& +0,312 \text { SIZE } \ldots \ldots \ldots \ldots \ldots \ldots(4)
\end{aligned}
$$

Berdasarkan model regresi yang terbentuk, dapat diinterpretasikan hal-hal sebagai berikut :

1. Nilai konstanta sebesar $-9,944$ menunjukkan bahwa jika nilai variabel likuiditas, reputasi KAP, opini audit tahun sebelumnya, dan ukuran perusahaan dianggap konstan (tidak ada perubahan), maka nilai opini audit going concern turun sebesar 9,944 satuan.

2. Koefisien regresi dari likuiditas adalah sebesar -1,562. Likuiditas tidak berpengaruh pada penerimaan opini audit going concern.

3. Koefisien regresi dari reputasi KAP adalah sebesar -19,116. Reputasi KAP tidak berpengaruh pada penerimaan opini audit going concern.

4. Koefisien regresi dari opini audit tahun sebelumnya adalah sebesar 5,628. Ini menunjukkan bahwa apabila opini audit tahun sebelumnya naik satu satuan dengan variabel lain yang konstan, maka nilai opini audit going concern akan naik 5,628 satuan.

5. Koefisien regresi dari ukuran perusahaan adalah sebesar 0,312. Ukuran perusahaan tidak berpengaruh pada penerimaan opini audit going concern.

\section{Pembahasan hasil penelitian}

1. Pengaruh likuiditas terhadap penerimaan opini audit going concern

Hasil pengujian hipotesis ini menunjukkan bahwa likuiditas tidak berpengaruh terhadap penerimaan opini audit going concern, dengan koefisien regresi negatif sebesar -1,562 dan nilai signifikansi 0,155 yang lebih besar dari 0,05. Hasil penelitian ini sejalan dengan penelitian yang dilakukan oleh Susanto (2009) dan Sutedja (2010) yang membuktikan bahwa likuiditas tidak berpengaruh terhadap penerimaan opini audit going concern. Hal ini menunjukkan bahwa auditor dalam memberikan opini audit going concern tidak hanya berdasarkan kemampuan perusahaan untuk membayar kewajiban jangka pendeknya, namun lebih cenderung melihat laporan keuangan perusahaan secara keseluruhan. 
2. Pengaruh reputasi KAP terhadap penerimaan opini audit going concern

Hasil penelitian menunjukkan reputasi KAP tidak berpengaruh terhadap penerimaan opini audit going concern, dengan koefisien regresi negatif -19,116 dan nilai signifikansi sebesar 0,998 yang lebih besar dari 0,05. Hasil penelitian ini sejalan dengan penelitian Arsianto \& Rahardjo (2013) serta Ramadhany (2004) yang membuktikan bahwa reputasi KAP tidak berpengaruh terhadap penerimaan opini audit going concern. KAP yang sudah memiliki reputasi baik akan berusaha untuk tetap menjaga reputasinya dengan cara bersikap objektif dimana jika suatu perusahaan diragukan kelangsungan usahanya maka auditor akan memberikan opini audit going concern. Oleh karena itu, KAP big four maupun non big four akan tetap memberikan opini audit going concern apabila perusahaan tersebut diragukan kelangsungan usahanya.

3. Pengaruh opini audit tahun sebelumnya terhadap penerimaan opini audit going concern

Hasil penelitian menunjukkan bahwa opini audit tahun sebelumnya berpengaruh positif terhadap penerimaan opini audit tahun sebelumnya, dengan nilai koefisien regresi positif 5,628 dan nilai signifikansi 0,000 yang lebih kecil dari 0,05. Hasil penelitian ini sejalan dengan penelitian Ramadhany (2004) serta Arsianto \& Rahardjo (2013) yang membuktikan bahwa opini audit tahun sebelumnya berpengaruh positif terhadap penerimaan opini audit going concern. Apabila pada tahun sebelumnya auditor mengeluarkan opini audit going concern, maka besar kemungkinan auditor akan memberikan kembali opini audit going concern pada tahun berikutnya. Namun pemberian kembali opini audit going concern tidak hanya didasari oleh opini audit tahun sebelumnya, tetapi hilangnya kepercayaan dari investor dan kreditur dapat menjadi masalah karena perusahaan akan semakin sulit untuk bangkit dan mempertahankan kelangsungan usahanya.

4. Pengaruh ukuran perusahaan terhadap penerimaan opini audit going concern

Hasil penelitian menunjukkan bahwa ukuran perusahaan tidak berpengaruh terhadap penerimaan opini audit going concern, dengan nilai koefisien regresi 0,312 dan nilai signifikansi sebesar 0,558 yang lebih besar dari 0,05. Hasil penelitian ini sejalan dengan penelitian Ramadhany (2004) dan Kristiana (2012) yang membuktikan bahwa ukuran perusahaan tidak berpengaruh terhadap penerimaan opini audit going concern. Praptitorini \& Januarti (2011)menyatakan bahwa kelangsungan hidup usaha selalu dihubungkan dengan kemampuan manajemen dalam mengelola perusahaan agar bertahan hidup. Oleh karena itu, meskipun sebuah perusahaan tergolong dalam perusahaan kecil, namun jika perusahaan tersebut memiliki manajemen dan kinerja yang bagus sehingga mampu bertahan dalam jangka panjang, maka semakin kecil potensi mendapatkan opini audit going concern. 


\section{SIMPULAN}

Berdasarkan analisis data serta pembahasan yang sudah dilakukan, maka dapat ditarik simpulan sebagai berikut :

1. Variabel likuiditas tidak berpengaruh terhadap penerimaan opini audit going concern. Hal ini dikarenakan auditor dalam memberikan opini audit going concern tidak hanya berdasarkan kemampuan perusahaan untuk membayar kewajiban jangka pendeknya, namun lebih cenderung melihat laporan keuangan perusahaan secara keseluruhan.

2. Variabel reputasi KAP tidak berpengaruh terhadap penerimaan opini audit going concern. Hal ini dikarenakan KAP yang sudah memiliki reputasi baik akan berusaha untuk tetap menjaga reputasinya dengan cara bersikap objektif dimana jika suatu perusahaan diragukan kelangsungan usahanya maka auditor akan memberikan opini audit going concern, terlepas dari apakah KAP tersebut merupakan KAP big four atau KAP non big four.

3. Variabel opini audit tahun sebelumnya berpengaruh positif terhadap penerimaan opini audit going concern. Hal ini dikarenakan besar kemungkinan auditor akan memberikan kembali opini audit going concern pada tahun berikutnya dan apabila suatu perusahaan sudah mendapatkan opini audit going concern maka besar kemungkinan perusahaan tersebut mengalami hilangnya kepercayaan dari investor maupun kreditur sehingga akan susah mempertahankan kelangsungan usahanya.

4. Variabel ukuran perusahaan tidak berpengaruh terhadap penerimaan opini audit going concern. Hal ini dikarenakan kemampuan manajemen menjadi peran penting dalam mempertahankan kelangsungan usaha suatu perusahaan. Meskipun sebuah perusahaan tergolong dalam perusahaan kecil, namun jika perusahaan tersebut memiliki manajemen dan kinerja yang bagus sehingga mampu bertahan dalam jangka panjang, maka semakin kecil potensi mendapatkan opini audit going concern.

\section{Saran}

Saran-saran yang dapat disampaikan berdasarkan penelitian ini adalah sebagai berikut :

1. Penelitian ini hanya dilakukan pada perusahaan manufaktur di Bursa Efek Indonesia pada tahun 2014-2016. Penelitian selanjutnya dapat melakukan penelitian pada sektor perusahaan lainnya seperti perusahaan properti, real estate, dan konstruksi bangunan, sektor keuangan, dan lain sebagainya.

2. Nilai koefisien determinasi (nagelkerke $R$ square) adalah sebesar $69,6 \%$ yang menunjukkan bahwa variabilitas variabel independen yang disajikan dalam variabel dependen adalah $69,6 \%$ sedangkan sisanya sebesar 30,4\% dapat dijelaskan oleh variabel-variabel lain yang 
dapat mempengaruhi opini audit going concern, contohnya audit tenure, disclosure, opinion shopping, dan lain sebagainya.

3. Tidak adanya pembanding dalam menentukan apakah perusahaan mengalami financial distress atau tidak. Peneliti selanjutnya diharapkan menambahkan pembanding untuk menentukan financial distress perusahaan seperti The Zmijewski Model dan The Springate Model.

\section{DAFTAR PUSTAKA}

Alichia, Y. P. (2013). Pengaruh Ukuran Perusahaan, Pertumbuhan Perusahaan, dan Opini Audit Tahun Sebelumnya terhadap Opini Audit Going Concern (Studi Empiris Perusahaan Manufaktur yang terdaftar pada Bursa Efek Indonesia. Universitas Negeri Padang.

Altman, E. I. (1968). Financial Ratios, Discriminant Analysis and the Prediction of Corporate Bankruptcy. The Journal of Finance, 23(4), 589-609.

Anita, W. F. (2017). Analisis Faktor-Faktor yang Mempengaruhi Opini Audit Going Concern pada Perusahaan Manufaktur yang Terdaftar di Bursa Efek Indonesia. Jurnal Riset Keuangan Dan Akuntansi, 3(2), 87-108. https://doi.org/https://doi.org/10.25134/jrka.v3i2.939

Anthony, R. N., \& Govindarajan, V. (2005). Management Control System (Edisi 11). Jakarta: Salemba Empat.

Ardiani, N., Nur DP, E., \& Azlina, N. (2012). Pengaruh Audit Tenure, Disclosure, Ukuran KAP, Debt Default, Opinion Shopping, dan Kondisi Keuangan terhadap Penerimaan Opini Audit Going Concern pada Perusahaan Real Estate dan Property di Bursa Efek Indonesia, 20(4), 1-21.

Arisandy, Z. (2015). Pengaruh Ukuran Perusahaan, Pertumbuhan Perusahaan, dan Opini Audit Tahun Sebelumnya terhadap Opini Audit Going Concern. Universitas Hasanuddin Makassar.

Arma, E. U. (2013). Pengaruh Profitabilitas, Likuiditas, dan Pertumbuhan Perusahaan terhadap Penerimaan Opini Audit Going Concern. Universitas Negeri Padang.

Arsianto, M. R., \& Rahardjo, S. N. (2013). Faktor-Faktor yang Mempengaruhi Penerimaan Opini Audit Going Concern. Diponegoro Journal of Accounting, 2(3), 1-8.

Brigham, E. F., \& Daves, P. R. (2007). Intermediate Financial Management (Ninth Edit). United States of America: Thomson South-Western.

Bursa Efek Indonesia. 2014. Laporan Keuangan Tahunan, http://web.idx.id. (Diakses pada tanggal 14 Februari 2018)

2015. Laporan Keuangan Tahunan, http://web.idx.id. (Diakses pada tanggal 14 Februari 2018)

2016. Laporan Keuangan Tahunan, http://web.idx.id. (Diakses pada tanggal 14 Februari 2018)

Darsono, \& Ashari. (2004). Pedoman Praktis Memahami Laporan Keuangan. Yogyakarta: Andi.

Edza, F. . (2015). Faktor-faktor yang Mempengaruhi Kecenderungan Penerimaan Opini Audit Going Concern pada Perusahaan Manufaktur yang Terdaftar di Bursa Efek Indonesia Tahun 20132014. Universitas Muhammadiyah Surakarta. Retrieved from http://eprints.ums.ac.id/38858/1/Naskah Publikasi.pdf

Ghozali, I. (2016). Aplikasi Analisis Multivariete dengan Program IBM SPSS 23. Semarang: BPFE Universitas Diponegoro.

Harahap, S. S. (2011). Analisis Kritis atas Laporan Keuangan. Jakarta: Raja Grafindo Persada.

Ikatan Akuntan Indonesia-Kompartemen Akuntan Publik (IAI-KAP). 2011. Standar Profesional Akuntan Publik. Jakarta: Salemba Empat.

Ikatan Akuntan Publik Indonesia. 2013. Standar Audit "SA" 570 tentang Kelangsungan Usaha. (Diakses pada tanggal 7 Mei 2018) 
2013. Standar Audit "SA" 700 tentang Perumusan Suatu Opini dan Pelaporan atas Laporan Keuangan. (Diakses pada tanggal 7 Mei 2018)

2013. Standar Audit "SA" 705 tentang Modifikasi terhadap Opini dalam Laporan Auditor Independen. (Diakses pada tanggal 7 Mei 2018)

Januarti, I., \& Fitrianasari, E. (2008). Analisis Rasio Keuangan dan Rasio Non Keuangan yang Mempengaruhi Auditor dalam Memberikan Opini Audit Going Concern pada Auditee (Studi empiris pada Perusahaan Manufaktur yang terdaftar di BEJ tahun 2000 - 2005). JURNAL MAKSI, 8(1), 43-58.

Junaidi, \& Hartono, J. (2010). Faktor Non Keuangan pada Opini Going Concern. In Simposium Nasional Akuntansi XIII (pp. 1-23). Universitas Jenderal Soedirman Purwokerto: Ikatan Akuntan Indonesia.

Kartika, A. (2012). Pengaruh Kondisi Keuangan dan Non Keuangan terhadap Penerimaan Opini Going Concern pada Perusahaan Manufaktur di BEI. Dinamika Akuntansi, Keuangan Dan Perbankan, 1(1), 25-40.

Kristiana, I. (2012). Pengaruh Ukuran Perusahaan, Profitabilitas, Likuiditas, Pertumbuhan Perusahaan terhadap Opini Audit Going Concern pada Perusahaan Manufaktur yang Terdaftar di Bursa Efek Indonesia (BEI). Berkala Ilmiah Mahasiswa Akuntasni, 1(1), 47-51.

Meriani, N. P., \& Krisnadewi, K. A. (2012). Pengaruh kondisi keuangan, Pertumbuhan Perusahaan, dan Reputasi Auditor pada Pengungkapan Opini Audit Going Concern. Jurnal Ilmiah Akuntansi Dan Bisnis, 7(1), 1-29.

McKeown, et al. Towards an Explanation of Auditor Failure to Modify the Audit Opinions of Bankrupt Companies. (1991). Auditing: A Journal of Practice and Theory. p.1-13

Pradika, R. A., \& Sukirno. (2017). Pengaruh Profitabilitas, Likuiditas, dan Ukuran Perusahaan terhadap Opini Audit Going Concern (Studi pada Perusahaan Manufaktur yang Terdaftar di Bursa Efek Indonesia tahun 2012-2015). Jurnal Profita, 5(5), 1-9.

Praptitorini, M. D., \& Januarti, I. (2011). Analisis Pengaruh Kualitas Audit, Debt Default dan Opinion Shopping terhadap Penerimaan Opini Going Concern. Jurnal Akuntansi Dan Keuangan Indonesia, 8(1), 78-93.

Rahayu, A. W., \& Pratiwi, C. W. (2011). Pengaruh Opini Audit Tahun Sebelumnya, Pertumbuhan Perusahaan, Leverage dan Reputasi Auditor terhadap Penerimaan Opini Audit Going Concern. In Proceeding PESAT (Psikologi, Ekonomi, Sastra, Arsitektur \& Sipil) (pp. 98-104). Depok: Universitas Gunadarma.

Rahman, A., \& Siregar, B. (2012). Faktor-faktor yang Mempengaruhi Kecenderungan Penerimaan Opini Audit Going Concern pada Perusahaan Manufaktur yang Terdaftar di Bursa Efek Indonesia. In Simposium Nasional Akuntansi XV (pp. 1-37). Banjarmasin: Ikatan Akuntan Indonesia.

Ramadhany, A. (2004). Analisis Faktor-faktor yang Mempengaruhi Penerimaan Opini Audit Going Concern. Jurnal MAKSI, 4, 146-160.

Republik Indonesia, Peraturan Menteri Keuangan No. 17/PMK.01/2008 tentang Jasa Akuntan Publik.

Rudyawan, A. ., \& Badera, I. D. N. (2009). Opini Audit Going Concern: Kajian Berdasarkan Model Prediksi Kebangkrutan, Pertumbuhan Perusahaan, Leverage, dan Reputasi Auditor. Jurnal Ilmiah Akuntansi Dan Bisnis, 4(2).

Santosa, A. F., \& Wedari, L. K. (2007). Analisis Faktor-faktor yang Mempengaruhi Kecenderungan Penerimaan Opini Audit Going Concern. Jurnal Akuntansi Dan Auditing Indonesia (JAAI), 11(2), 141-158.

Sari, K. (2012). Analisis Pengaruh Audit Tenure, Reputasi KAP, Disclosure, Ukuran Perusahaan dan Likuiditas terhadap Penerimaan Opini Audit Going Concern (Studi Empiris pada Perusahaan Manufaktur yang Listing di BEI tahun 2005-2010). Universitas Diponegoro Semarang.

Susanto, Y. K. (2009). Faktor-faktor yang Mempengaruhi Penerimaan Opini Audit Going Concern pada Perusahaan Publik Sektor Manufaktur. Jurnal Bisnis Dan Akuntansi, 11(3), 155-173.

Sussanto, H., \& Aquariza, N. M. (2012). Analisis Pengaruh Opini Audit Tahun Sebelumnya, Kualitas Auditor, Profitabilitas, Likuiditas dan Solvabilitas terhadap Pemberian Opini Audit Going Concern pada Perusahaan Consumer Goods Industry yang Terdaftar di Bursa Efek Indonesia. 
UG Jurnal, 6(12), 14-19.

Sutedja, C. (2010). Faktor-faktor yang Berpengaruh terhadap Pemberian Opini Audit Going Concern pada Perusahaan Manufaktur. Jurnal Akuntansi Kontemporer, 2(2), 153-168.

Widyasaputri, E. (2012). Analisis Mekanisme Corporate Governance pada Perusahaan yang Mengalami Kondisi Financial Distress. Accounting Analysis Journal, 1(2), 1-8. 